American Journal of Economics and Business Administration 3 (3): 460-472, 2011

ISSN 1945-5488

(C) 2011 Science Publications

\title{
Trade Promotions and Suppliers' Market Power
}

\author{
Sandra Mottner, Steven H. Smith and T.J. Olney \\ Department of Marketing, College of Business and Economics, 415 High Street, \\ MS 9073 Bellingham, Western Washington, 98225, WA
}

\begin{abstract}
Problem statement: Trade promotions provided to retailers from suppliers are not well understood and have not been consistently reported by manufacturers. Research about the phenomenon has consequently been limited and neither the trade nor government agencies fully understand the phenomenon and its implications. One implication is that some trade promotions (or trade allowances as they are also known) can pose an ethical dilemma in terms of restricting competition to the disadvantage of smaller businesses. Approach: This research takes advantage of a one-time release of data at the individual firm level which includes firm specific information on trade promotions, which includes slotting fees, provided by manufacturers for placement in retail stores as well as advertising and promotion support for the retailer. Firm level specific data gives the researcher a method of analyzing the use of market power exercised by the manufacturer to influence retail behavior. Further, the analysis of trade promotion practices and market power give an indication of possible uncompetitive conditions created by manufacturers with high potential market power. Results: Findings indicate that firms with high potential market power, based on assets, provide more trade promotions. Firms with high profits derived from high gross margins, also exercise high market power. Both of these findings, in terms of potential market power as well as exercised market power, lend credibility to the argument that high market power firms pose an uncompetitive environment for small suppliers. Conclusion/Recommendations: The Federal Trade Commission (FTC), which previously reviewed this issue, needs to revisit the matter in terms of the creation of the uncompetitive environment that appears to be created through high market power firms. Further, research that considers both the retail and manufacturers' firm-level data on a broad spectrum should be examined to better understand the situation.
\end{abstract}

Key words: Trade promotion, slotting fee, uncompetitive environment, restrict competition, Federal Trade Commission (FTC), firm-level data, market power, potential market

\section{INTRODUCTION}

Trade promotions are usually negotiated reductions in invoiced dollars from manufacturers to retailers and are not a particularly new phenomenon. However, research into how they work, particularly from a supplier's perspective, needs considerable development. The lack of firm-level data has seriously hampered the research into trade promotions, as most firms (retailers and manufacturers) have been reluctant to disclose their actual amounts (Gomez et al., 2007). It is likely that a major reason for the reluctance to disclose the financial information stems from the fact that trade promotions include slotting fees (among other promotional support) and have been the subject of much scrutiny for possibly being anti-competitive in nature (FTC, 2001). Debate and discussion about trade promotions have been ongoing for years, due in large part to the lack of data and lack of solid empirical research that has resulted from the lack of information (Nijs et al., 2010). Therefore, this study takes advantage of a one-time release of manufacturers' data on trade promotions and demonstrates how the trade promotions relate to the market power of manufacturers.

As noted, trade promotions include slotting fees, which are payments for advantageous shelf placement, cooperative advertising support and discounts on large quantity sales (Gomez et al., 2007). Additionally, since the trade promotions are normally made as a reduction to the invoice, they are also known as trade allowances and the terms are used interchangeably. To stay consistent, this study uses trade promotions exclusively in lieu of trade allowances or slotting fees. Trade promotions are used by manufacturers to influence the behavior of retailers with respect to shelf placement, addition of a new product, quantity purchased, or other promotional support of a particular brand or item. Retailers, who often demand or negotiate the trade promotions have been happy to

Corresponding Author: Sandra Mottner, Department of Marketing, College of Business and Economics 415 High Street, MS 9073 Bellingham, Western Washington, 98225, WA Tel: 360-650-2403 Fax: 360-650-4844 


\section{Am. J. of Economics and Business Administration 3 (3): 460-472 2011}

receive the reductions in their costs, which in their perspective, reduces risk-particularly from new product failure- and helps to mitigate the cost of retailer advertising (Zerrillo and Iacobucci, 1995).

Relative market power between the suppliers (manufacturers) and retailers is thought to affect the amount of trade promotion (Zerrillo and Iacobucci, 1995). From one perspective, manufacturers influence the behavior of retailers through offering generous trade promotions to retailers who consequently have less control of their own activities and hence their power (relative to the manufacturers) has been diminished in some respects. Manufacturers with more market power have the ability (whether they use it or not) to exert greater control at the consumer's point of purchase than manufacturers with less market power. Conversely, in a market where many argue that retail market power has increased considerably over manufacturer's market power (Kelly and Gosman, 2000) the retailers' market power may be used to extract excessive trade promotions from suppliers. An examination of a possible market power shift between suppliers and retailers is beyond the scope of this study. However, this research does examine the relative exercised market power among suppliers and draws implications for retailers from the findings. One of the key questions is whether the exercised market power of large manufacturers makes an uncompetitive environment for small manufacturers, as has been argued before the FTC in the case trade promotions provided (FTC, 2001).

This study specifically seeks to understand the nature and measurement of market power from one perspective the manufacturer's and the amount of trade promotion it uses. The results of the research will shed light on the phenomenon of retailer and manufacturer relative market power but more on the nature of market power of manufacturers and their use of trade promotions. In particular, the measurement and definition of market power will be examined and it will be demonstrated that various manifestations of market power have differing effects upon trade promotion. Further, the role of industry type and competitive intensity within given industries will be tested to determine the relative importance of the trade promotion phenomenon in certain industries (product groups) relative to others. Finally, the relationship of promotion and advertising expenditures (exclusive of trade promotions) relative to trade promotions spending on the part of manufacturer will be examined. The pass-through of savings from trade promotions to consumers is beyond the scope of this study and has been examined recently (Ailawadi and Harman, 2009; Nijs et al., 2010).
Trade promotions: Trade promotions lower the cost of merchandise and/or advertising from the manufacturer and the reductions are passed to the retailer as special terms on invoices (Skibo, 2007). Examples of trade promotions include bulk purchases that are larger than normal for which the retailer receives a discount (Ailawadi et al., 1999), slotting fees for new product placement (Buzzell et al., 1990), slotting fees to maintain a presence on a store shelf (FTC, 2001; Bloom et al., 2000), in-store display promotions (Murry and Heide, 1998), freight rebates (Skibo, 2007) and advertising and promotional support including co-op advertising, manufacturer supported contests and demonstrations (Kasulis et al., 1999). The practice is primarily, but not exclusively, associated with the grocery retail industry (Zerrillo and Iacobucci, 1995).

Invoice terms may be discount-based or performance-based (Gomez et al., 2007). Discountbased terms mean that the savings to the retailer are taken directly "off-invoice" and retailers realize the savings immediately (Bell and Dreze, 2002). Examples of performance-based terms include reductions on future invoices for exceeding sales goals and for proof of advertising in order to receive the co-op advertising reimbursement. Manufacturers also offer financial terms, such as extended payment schedules as an incentive, or waive freight charges as an incentive to place an order at a certain time (Skibo, 2007).

The various types of trade promotions and the methods of providing off-invoice allowances indicate that the trade promotion represents a complex phenomenon that takes time to negotiate and/or communicate. Indeed, the literature presents strong evidence that the amount and variety of trade promotions grow at a greater rate than more conventional advertising and promotion expenses (Gomez et al., 2007) which show a relative decrease (Nijs et al., 2010). Together, the growth in trade promotion activity, the individual negotiations necessary, the complexity of types of trade promotions and the lack of data surrounding the activity underscore the need for a greater understanding of the phenomenon.

Additionally, the magnitude of trade promotions compared to advertising expenses proves significantly larger for brand manufacturers (Gomez et al., 2007) and indeed constitutes the majority of most manufacturers' marketing budgets (Pauwels, 2007). Interestingly, the tobacco industry, which has been increasingly restricted in its advertising campaigns in the U.S. has been aggressively pursuing trade promotions with retailers in order to influence signage, product location and other retailer-focused incentives. 
Unfortunately, due to a multitude of methods used to account for trade promotions in the past, it has been impossible to follow this trend clearly from public accounting statements. It is also obvious that inconsistent accounting practices among manufacturers had been helping to make the amount of actual advertising and promotional expenses versus trade promotions, which are netted against sales, unclear. Further, there has been a refusal to disclose trade promotions, which has further hampered research. Indeed, research into trade promotions overall has been hampered by the lack of data (Gomez et al., 2007: Nijs et al., 2010).

Legal, ethical and efficiency arguments have focused on trade promotions for more than a decadewith an emphasis on implications of unfair competition. While these arguments are highly related, the literature has focused on each with differing degrees of intensity. The legal arguments generally focus on antitrust issues and the potential plaintiffs: small manufacturers, small retailers and the Federal Trade Commission (FTC) (Cannon and Bloom, 1991). Small manufacturers argue that trade promotions are onerous, but to get their products shelved, small manufacturers must provide trade promotions and sometimes at rates higher than those provided by larger manufacturers (Cannon and Bloom, 1991; Kelly, 1991). The Robinson-Patman Act, which deals with price and promotional discrimination, is the law that is most likely violated by current trade promotion practices (Cannon and Bloom, 1991). Small manufacturer's complaints about trade promotions reflect the general market power issue. Overall, the question that this research seeks to answer is how manufacturer trade promotions reflect manufacturer market power.

Market power and trade promotions: Market power is the relative bargaining position and ability of one firm over another in the marketing channel. Market power is either exercised or potential in nature and measurement for exercised or potential market power types differ (Ailawadi et al., 1995). Market power is held by a variety of players in the distribution channel including the manufacturers, distributors, retailers and consumers. A manufacturer's market power is defined in potential terms as being, "those industry characteristics or conditions having the potential to affect the manufacturer's power in the marketplace" (Butaney and Wortzel, 1988). Retailers, on the other hand have the potential to indirectly intensify price competition among manufacturers (Draganska and Klapper, 2007).

Some literature insists that retailers in general are gaining market power relative to manufacturers based on industry consolidations (Zerrillo and Iacobucci, 1995); however, the evidence for grocery retailers is opposite (Ailawadi et al., 1995). Additionally, a longitudinal analysis of large public retailers of all types found that only Wal-Mart was gaining in financial performance (Evans, 2005) while all other retailers experienced no significant change in financial performance. Financial performance represents a proxy for market power, hence there is scant evidence that a shift in market power is occurring. Interestingly, despite Wal-Mart's obvious market power, it does not extract trade promotions from its suppliers (Useem, 2004). Instead, Wal-Mart negotiates price breaks from its suppliers and thus maintains more control over the display, placement and marketing of its merchandise than do retailers that extract trade promotions. However, Wal-Mart engages in very aggressive promotional support negotiations (Walton, 2004-2005) and thus exerts market power while maintaining more internal control of its marketing and merchandising practices (placement of goods) than other retailers.

Given that market power and bargaining power go hand-in-hand, it is likely that manufacturers with the greatest amount of market power would be able to negotiate the best terms with retailers. However, the nature of those terms will vary. High market power manufacturers may provide large trade promotions in order to stifle competition from smaller manufacturers. Conversely, high-power manufacturers may have stronger brand loyalty or support their product through other means (e.g., advertising) than do low market power firms, who are forced to provide higher trade promotions (Cannon and Bloom, 1991; Kelly, 1991).

This apparent divergence in the relationship between the amount of trade promotions allowed by a manufacturer and the manufacturer's market power suggests that the relationship between market power and trade promotions should be examined from various perspectives with respect to the nature and the measurement of market power. Indeed, one of the key issues in the literature of market power is how to measure it (Ailawadi et al., 1995). Traditional measures of market power have been in economic terms (usually profit) and tend to reflect a firm's pricing power. A less traditional measure of market power is in terms of brand equity (Sivakumar, 2004), or the manufacturer's market power in "owning the brand" (Wood, 1999). Ailawadi et al. (1995) in-depth examination of market power argued that while profits captured some aspects of market power, market power is related to the cost structure of the company return on equity and cost of capital. They proposed and tested a number of "Economic Value Added" (EVA) measures of market power. The implication of their research is that multiple measures of market power are strongly indicated. 
Am. J. of Economics and Business Administration 3 (3): 460-472 2011

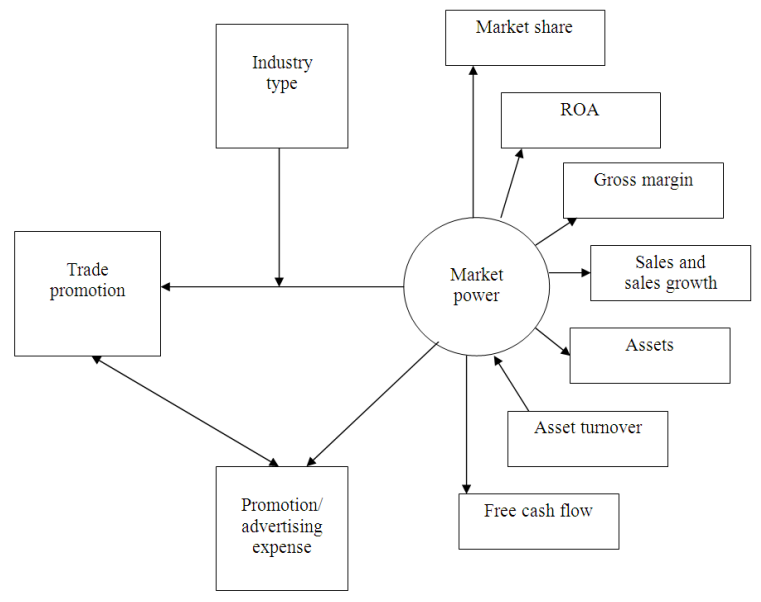

Fig. 1: Trade promotion and market power

For purposes of this research, the market power is examined along two lines: "potential" and "exercised" market power (Ailawadi et al., 1995). Potential market power represents a firm's dominance in the marketplace relative to other firms. Therefore, potential market power measurements are generally associated with a firm's size. Larger firms are more powerful in the marketplace of products and are able to use this power to protect their competitive position. For example, Rao and Mahi (2003) posit that one interpretation of their findings is that higher trade promotions are extracted from manufacturers with the ability and willingness to pay. Indeed, if this is true, it lends credibility to the argument that larger manufacturers with higher market power can erect barriers to entry to smaller firms with less market power. Large firms with potential market power would be characterized as those firms having high market share, high sales and high sales growth (Gomez et al., 2007) that can be used for more effective bargaining of trade promotion terms. Arguably, a manufacturer's assets provide a measure of potential market power if those assets can be translated into dominance in the marketplace. This resource-based view of the firm indicates that large assets are aligned with competitive dominance. More meaningfully, free cash flow relates directly to the manufacturer's freedom to potentially exercise its market dominance.

While size, measured by a number of means, indicates potential market power, profitability measures a firm's exercised market power and its ability to extract excess returns from its customers. When high profitability is used as a measure of high market power, it captures a firm's ability to price its product to earn higher returns or to eliminate costs that do not provide commensurate returns. However, as Ailawadi et al., (1995) point out, profit alone is a very incomplete measure of market power. In the case of trade promotions, higher profit will result from the judicious use trade promotions and indicates that the manufacturer has more bargaining power over retailers. Higher profit, especially when correlated with higher gross margin will indicate that fewer price concessions are made (or exercised) by the manufacturer.

ROA has also been used as a measure of relative market power as it combines the potential market power measure of assets with the exercised market power measure of profit. Here, the market power measures, both potential and exercised, are not being used to assess the relative power of retailers to manufacturers, but rather to assess the degree to which market power affects the amount of trade promotion provided to retailers. Indeed, manufacturers may decide to use trade promotions for strategic reasons even when retailers do not pass the savings on to customers-rather, manufacturers appear to use trade promotions as a competitive tool (Silva-Risso et al., 1999).

Hence, a model of market power as measured by the terms discussed above is shown in Fig. 1. Not pictured in Fig. 1 is the obvious fact that the amount of trade promotion offered or negotiated with retailers is not completely dependent upon the relative market power of manufacturers one to another. However, the presumption is that firms exercise higher market power to either gain or maintain a competitive advantage through trade promotions or other means (such as advertising) and hence, not surprisingly, firms with high exercised market power will generally have higher trade promotions. Firms with low potential market power will be unable to meet the trade promotion levels provided by more powerful manufacturers. In general, it is expected that trade promotions provided by manufacturers will vary based on the measurement of market power used but that overall, firms with more market power, either exercised or potential, will provide more trade promotions.

However, it is also expected that the market power of manufacturers and the amount of trade promotion will be moderated in two important variables, advertising expense and industry type, as shown in Fig. 1.

Market power, trade promotion and advertising expense: As noted earlier there is considerable evidence that manufacturers are reducing traditional advertising and promotion expenses for more retailerfocused trade promotions (Gomez et al., 2007; Zerrillo and Iacobucci, 1995). However, a manufacturer has greater market power when it has a strong brand or brands especially brand loyalty and brand equity. High brand power can be supported by both advertising and 
promotion expense and by trade promotions. However, trade promotions that focus primarily on price concessions, which may be passed on at least in part to the consumer, do not indicate brand value. Rather, a manufacturer with a strong brand or brands should minimize off-price trade promotions and focus on trade promotions that are part of the overall integrated marketing communication strategy such as in-store signage, co-op advertising support and similar activities (Kasulis et al., 1999). Consequently, it is expected that there will be an inverse relationship between trade promotions and traditional advertising and promotional expenses. The alternative to the market power argument is that trade promotions efficiently diversify the risk of product failure between the retailer and the manufacturer. We include several control variables in our empirical models to control for the efficiency arguments and industry differences. Additionally, it is expected that those firms with greater amounts of traditional advertising and promotion expense, which supports the development of strong long-term brand value, will have lower trade promotions despite the manufacturer's level of market power.

Industry type and competitive intensity: Different industry types (or product categories) have different characteristics which should affect the relationship between manufacturers and retailers. For example, Draganska and Klapper (2007) demonstrate that there are differences in retailer/manufacturer market power relationships based on competitive intensity between brands within a product category. Competitive intensities vary by industry. Market power in the channel between retailers and manufacturers is affected by the competitive intensity within different industries (Kadiyali et al., 2000).

From the manufacturers' standpoint the competitive intensity within an industry is generally understood as having a high level of concentration with a high probability of vying for the same pool of resources that may include customers (Barnett, 1997). Auh and Menguc, 2005) define competitive intensity as, "a situation where competition is fierce due to the number of competitors in the market and the lack of potential opportunities for further growth. In the case of most trade promotions offered to retailers, manufacturers are competing with one another for shelf space in the store, for amount of product purchased, for positioning in the store, for signage, for point of purchase promotions and for manufacturer supported advertising space and locations-especially in the grocery industry. Competitors within manufacturing categories have displayed differences in competitor responses with respect to the size of a product category and the concentration level of the category (Pauwels, 2007). Therefore, while different manufacturers within a product category have differing degrees of market power, it is expected that a level of competitive intensity is distinct to different product categories and the product categories will therefore have a moderating effect on the relationship between manufacturer's market power and the trade promotions provided to retailers as shown in Fig. 1.

\section{MATERIALS AND METHODS}

In 2001, the Emerging Issues Task Force (EITF) of the HANS (2007) adopted Issue No. 01-9, "Accounting for Consideration Given by a Vendor to a Customer or a Reseller of the Vendor's Products." Issue No. 01-9, which codified and reconciled several previous issues, proscribes the proper income statement classification for trade promotions provided from a vendor to a reseller. Trade promotions include, but are not limited to: Rebates, free products, volume rebates, placement fees, cooperative advertising arrangements and buydowns. Previously, no specific accounting treatment for trade promotions had been required, but many manufacturers treated the expenses as operating costsspecifically advertising and promotional expenses. After the accounting treatment change, free products and gifts are treated as a reduction of costs of goods sold and the other give-backs are treated as reductions of sales. The accounting change had no effect on firms' net incomes, but was merely a reclassification of expenses. Firms were required to disclose the effect of the change in accounting method for trade promotions in their publicly filed financial statement footnotes and most firms adopted the new accounting method for reporting years beginning after December 15, 2001. The change in accounting method presents a window of opportunity to examine the manufacturers' characteristics that are correlated with the amounts provided.

Sample: To identify firms for our sample, we used the Mergent Online database, which includes 10,000 publicly-traded U.S. companies. We primarily targeted manufacturing firms that either had Standard Industry Classification (SIC) code of 20-28xx (non-durable consumer goods), which limited the search to food producers and producers of household chemicals. We limited our search to these manufacturers because we were interested in manufacturers that sell primarily to grocery and similar retail stores, which are likely to have similar trade promotion policies. 
Using the SIC code initial criteria, Mergent Online identified 164 U.S. public firms. We used this sample as a starting point to hand-collect trade promotion data and other financial data from the firms' financial statements available on Security and Exchange Commissions' online electronic filing system (EDGAR). During data collection, numerous firms were eliminated from the initial sample. We eliminated firms in bankruptcy or with terminated operations (34 firms); firms that primarily sell directly to consumers or to third-party distributors (39 firms); and firms with incomplete trade promotion disclosures (14 firms). We also eliminated beer, wine and spirit firms since distribution of their products is highly regulated and governed by state laws (13 firms). Thus, we were left with 66 useable U.S. public firms and 193 firm-year observations.

Model specification: The basic model for measuring trade promotion (Fig. 1) as predicted by the market power of suppliers is specified as follows:

Trade Promotion $=$ Potential Market Power + Exercised Market Power + ROA

TradePro $=\beta_{0}+\beta_{1} \ln \operatorname{Size}+\beta_{2} \operatorname{lnROA}+$

$\beta_{3} \ln$ Advert $+\beta_{4} \ln$ SaleG +

$\beta_{5} \operatorname{lnOp} \$$ Flo $+\beta_{6} \operatorname{lnForeign}+\beta_{7} \mathrm{SIC}_{\mathrm{i}}+\varepsilon_{\mathrm{i}}$

Identifications of the variables are specified in Table 1. The equation is estimated using an ordinary least squares and is used to test the idea that high market power results in higher trade promotions. Note that as desirable as a Simultaneous Equation Modeling might be for estimating the diagrammed model, the data available were not adequate to run SEM.

In addition to the model above, several alternative model specifications are examined using the strategic profit model as guidance (Evans, 2005). The alternative specifications substitute components of Return On Assets (ROA) to more finely specify which components of ROA affect trade promotions. Model 2 uses a firstlevel breakdown and substitute's net profit margin (a measure of profitability) and turnover (a measure of operational efficiency) into the model for ROA. Model 3 uses a second-level breakdown and substitutes gross profit margin (a measure of pricing power) and the total expense ratio (a measure of organizational control) for net profit margin.

Generally, if manufacturers had more power over retailers, then it would be expected that manufacturers would resist providing trade promotions. Conversely, if the market power lies with retailers, then it would be expected that retailers could exert more power over manufacturers and demand more trade promotions.
Previous research has indicated a power shift from manufacturers to retailers (Ailawadi et al., 1995). While research has not found a power shift (Evans, 2005), it is a commonly held belief among manufacturers. Several manufacturers made reference to this alleged shift in market power and the demand for trade promotions in interviews. One major firm respondent indicated that, "in recent years there has been significant consolidation in the grocery industry through acquisitions. We have sought to establish and strengthen our alliance with key customers by offering ... applications to assist in managing inventories," (Similarly, another major firm employee stated that, "retail consolidation has increased and the importance of major customers and further consolidation is expected." Finally, one small manufacturer noted that, "the company is continually faced with demands for up-front concession, such as trade promotions; from major retailers ... the company's reluctance to pay these charges may inhibit the overall distribution of some items in certain markets or geographic regions." While our sample data is not longitudinal and does not allow us to examine the shift in trade promotions provided over a long time span, at least anecdotally, manufacturing firm managers feel some increased pressure to offer more trade promotions to move product.

Descriptive statistics: While data for every firm in our sample for each year is not available, we can make some estimates for the trade promotions provided for the 2000-2999 SIC manufacturers. In 2000, 57 firms in our sample reported providing trade promotions of almost $\$ 19.5$ billion. In 2001, 53 firms reported providing \$21.6 billion in trade promotions. However, it should be noted that trade promotion practices vary by industry type and the SIC code examined in this research is most likely to have the highest degree of trade promotions. Industrywide figures for the amount of trade promotions provided have varied significantly, but the figures reported here are arguably more accurate than prior estimates. The most current figure reported is, that across all industries in the U.S., the amount of trade promotions totals $\$ 75$ billion annually (Nijs et al., 2010).

To examine differences in trade promotions within industries, sample firms were grouped by their threedigit SIC code. The mean trade promotion was calculated for each industry group and the Ryan-EinotGabriel-Welsch multiple range procedure was used to test for significant differences between the groups (Einot and Gabriel, 1975). Table 2 provides the three digit SIC code, industry group description, the industry group mean trading promotions amount as a percent of sales, number of sample firms and observations in each industry group and statistical tests difference between 
Am. J. of Economics and Business Administration 3 (3): 460-472 2011

groups. The results indicate that firms selling grain mill products (SIC 204×) on average provide significantly more trade promotions than any other industry group at $16.8 \%$. The high trade promotion for the grain mill products is not totally unexpected because this group includes cereal manufacturers, which are generally considered to provide high trade promotions.
Processed fruits and vegetables (SIC 203x), beverages (SIC 208) and bakery goods (SIC 205) also provide a significant percentage of trade promotions: $10.0,7.1$ and $7.1 \%$, respectively. The remaining cluster of firm's trade promotions range from $4.9 \%$ for sugar and confectionary products (SIC $206 \times$ ) to $0.9 \%$ for meat products (SIC 201×).

Table 1: Variable descriptions

\begin{tabular}{|c|c|c|c|}
\hline \multirow{2}{*}{$\begin{array}{l}\text { Dependent variable } \\
\text { Trade promotions TradePro } \\
\text { Explanatory variables }\end{array}$} & \multicolumn{3}{|c|}{$\begin{array}{l}\text { Description } \\
\text { Trade promotions divided by sales, net of trade promotions }\end{array}$} \\
\hline & Model & Description operationalized & Rationale \\
\hline Firm size $\operatorname{lnSize}$ & $1,2,3$ & $\begin{array}{l}\text { Natural logarithm of a } \\
\text { firm's total assets. }\end{array}$ & $\begin{array}{l}\text { Larger firms have more market power and provide higher } \\
\text { trade promotions. }\end{array}$ \\
\hline Return on assets $\ln R O A$ & 1 & $\begin{array}{l}\text { Net profit before interest } \\
\text { and taxes, divided total assets. }\end{array}$ & $\begin{array}{l}\text { Firms with higher returns have more market power and provide } \\
\text { more trade promotions }\end{array}$ \\
\hline Net Profit margin lnNetPM & 2 & $\begin{array}{l}\text { Net profit before interest and } \\
\text { taxes, divided by lagged net sales. } \\
\text { (Ailawadi and Harlam, 2009) }\end{array}$ & $\begin{array}{l}\text { 1st level break down of ROA into its components } \\
\text { Firms with higher profitability have more power and provide } \\
\text { more trade promotions. }\end{array}$ \\
\hline Gross margin lnGrM & 3 & $\begin{array}{l}\text { Net sales less cost of goods } \\
\text { sold divided by lagged net sales. }\end{array}$ & $\begin{array}{l}\text { 2nd level break down of ROA. Gross profit margin } \\
\text { is a cleaner measure of pricing power and higher } \\
\text { margins = higher market power }\end{array}$ \\
\hline Tot Expense ratio $\operatorname{lnExp}$ & 3 & $\begin{array}{l}\text { SG andA expenses divided } \\
\text { by lagged net sales. }\end{array}$ & $\begin{array}{l}\text { 2nd level break down of ROA. } \\
\text { Expense ratio is the other component that } \\
\text { with gross margin makes up net profit margin. }\end{array}$ \\
\hline Turnover $\ln$ Turns & 2,3 & $\begin{array}{l}\text { Lagged net sales divided by } \\
\text { total assets. }\end{array}$ & $\begin{array}{l}\text { 1st level break down of ROA } \\
\text { Together margin and turnover make up return on assets. }\end{array}$ \\
\hline Advertising $\ln$ Advert & $1,2,3$ & $\begin{array}{l}\text { Total advertising costs, excluding } \\
\text { trade promotions, divided by } \\
\text { lagged net sales. }\end{array}$ & $\begin{array}{l}\text { A control variable. Firms that provide more } \\
\text { advertising may have lower product risk }\end{array}$ \\
\hline Sales growth $\operatorname{lnSalesG}$ & $1,2,3$ & $\begin{array}{l}\text { Percentage sales increase in the } \\
\text { current period over the prior } \\
\text { period }\left(\text { Sales }_{0}-\text { Sales }_{-1}\right) / \text { Sales }_{-1} \text {. }\end{array}$ & $\begin{array}{l}\text { A control variable. Firms with higher sales growth } \\
\text { may have lower product risk }\end{array}$ \\
\hline Operating \$ flow lnOp\$Flo & $1,2,3$ & $\begin{array}{l}\text { Current year operating cash flows } \\
\text { divided by lagged net sales. }\end{array}$ & $\begin{array}{l}\text { A control variable. Firms with higher operating } \\
\text { cash flow may have more ability to provide } \\
\text { more trade promotions }\end{array}$ \\
\hline Foreign sales $\operatorname{lnForeign}$ & $1,2,3$ & $\begin{array}{l}\text { Non-North American sales divided } \\
\text { by total lagged sales }\end{array}$ & $\begin{array}{l}\text { A control variable. Trade promotions in foreign } \\
\text { jurisdictions may differ. }\end{array}$ \\
\hline $\begin{array}{l}\text { SIC } \\
\text { SIC }\end{array}$ & $1,2,3$ & $\begin{array}{l}\text { Three digit standard industry } \\
\text { classification }\end{array}$ & $\begin{array}{l}\text { A control variable. Controls for industry differences } \\
\text { that may affect trade promotions provided } \\
\text { (Butaney and Wortzel, 1988) }\end{array}$ \\
\hline
\end{tabular}

${ }^{1}$ Independent variables are scaled by lagged net sales, when appropriate, rather than current net sales, because scaling the dependent and independent variables by the same value induces correlation. Model: (1) TradePro $=\beta_{0}+\beta_{1} \ln \operatorname{Size}+\beta_{2} \ln R O A+\beta_{3} \ln A d v e r t+\beta_{4} \ln S a l e G+$ $\beta_{5} \operatorname{lnOp} \$$ Flo $+\beta_{6} \ln$ Foreign $+\beta_{7}$ SIC $_{i}+\varepsilon_{I}(2)$ TradePro $=\beta_{0}+\beta_{1} \ln$ Size $+\beta_{2} \operatorname{lnNetPM}+\beta_{3} \ln$ Turns $+\beta_{4} \ln$ Advert $+\beta_{5} \operatorname{lnSaleG}+\beta_{6} \operatorname{lnOp} \$$ Flo + $\beta_{7} \operatorname{lnForeign}+\beta_{7} \mathrm{SIC}_{\mathrm{i}}+\varepsilon_{\mathrm{i}}$ (3) TradePro $=\beta_{0}+\beta_{1} \ln$ Size $+\beta_{2} \operatorname{lnGrM}+\beta_{3} \operatorname{lnExpM}+\beta_{4} \operatorname{lnTurns}+\beta_{5} \ln$ Advert $+\beta_{6} \ln$ SaleG $+\beta_{7} \operatorname{lnOp} \$$ Flo + $\beta_{8} \ln$ Foreign $+\beta_{9} \mathrm{SIC}_{\mathrm{i}}+\varepsilon_{\mathrm{i}}$

Table 2: Mean industry group trade promotions

\begin{tabular}{lllll}
$\begin{array}{l}\text { Three digit } \\
\text { SIC code }\end{array}$ & Industry group description & $\begin{array}{l}\text { Mean trade promotions } \\
\text { as a percent of sales }\end{array}$ & $\begin{array}{l}\text { \# of firms } \\
\text { (observations) }\end{array}$ & $\begin{array}{l}\text { Means with same letter are not } \\
\text { significantly different }\end{array}$ \\
\hline 204 & Grain mill products & 16.80 & $515)$ & A \\
203 & Canned, frozen and preserved fruits and vegetables & 10.00 & $11(28)$ & B \\
208 & Beverages & 7.10 & $6(16)$ & BC \\
205 & Bakery products & 7.10 & $6(15)$ & BC \\
206 & Sugar and confectionary products & 4.90 & $5(18)$ & CD \\
284 & Soap, detergents and cleaning preparations & 3.90 & $14(40)$ & CD \\
202 & Dairy products & 3.80 & $4(14)$ & CD \\
209 & Misc. food preparations and kindred & 3.60 & $7(21)$ & CD \\
201 & Meat products & 0.90 & & D \\
\hline
\end{tabular}


Am. J. of Economics and Business Administration 3 (3): 460-472 2011

Table 3: Descriptive statistics

\begin{tabular}{|c|c|c|c|c|c|c|}
\hline Description $^{1}$ variable name & Mean (Std. Dev.) & Minimum value & First quartile & Median & Third quartile & Maximum value \\
\hline Trade promotions & 0.060 & 0.000 & 0.000 & 0.037 & 0.102 & 0.299 \\
\hline TradePro & $(0.068)$ & & & & & \\
\hline Total assets & 3.6 bil & 47.655 & $37.100 \mathrm{mil}$ & $468.500 \mathrm{mil}$ & 2.900 bil & 55.800 bil \\
\hline Size & (8.3 bil) & & & & & \\
\hline Return on assets & 0.121 & -0.339 & 0.071 & 0.114 & 0.168 & 0.710 \\
\hline ROA & $(0.101)$ & & & & & \\
\hline Net profit margin & 0.095 & -0.237 & 0.046 & 0.082 & 0.145 & 0.303 \\
\hline NetPM & $(0.076)$ & & & & & \\
\hline Gross profit margin & 0.362 & 0.046 & 0.231 & 0.355 & 0.460 & 0.998 \\
\hline $\mathrm{GrM}$ & $(0.167)$ & & & & & \\
\hline Total expense ratio & 0.267 & 0.042 & 0.131 & 0.262 & 0.342 & 0.899 \\
\hline $\operatorname{Exp}$ & $(0.154)$ & & & & & \\
\hline Turnover & 1.598 & 0.298 & 1.071 & 1.454 & 2.008 & 4.525 \\
\hline Turns & $(0.798)$ & & & & & \\
\hline Advertising/lag sale & 0.043 & 0.000 & 0.001 & 0.022 & 0.058 & 0.500 \\
\hline Advert & $(0.065)$ & & & & & \\
\hline Sales growth & 0.097 & -0.243 & 0.014 & 0.065 & 0.138 & 0.914 \\
\hline SaleG & $(0.160)$ & & & & & \\
\hline Op \$ Flo/lag sale & 0.084 & -0.129 & 0.041 & 0.073 & 0.130 & 0.266 \\
\hline Op\$Flo & $(0.065)$ & & & & & \\
\hline Foreign sale/lag sale & 0.121 & 0.000 & 0.000 & 0.000 & 0.162 & 0.751 \\
\hline Foreign & $(0.201)$ & & & & & \\
\hline
\end{tabular}

Table 3 provides descriptive statistics for the entire sample. Trade promotions granted are on average $6.0 \%$ of sales, with one firm providing as much as $29.9 \%$. Our sample size ranged from one firm with just over $\$ 47,600$ in total assets to another firm with $\$ 55.5$ billion in assets, the average being $\$ 3.6$ billion. ROA ranges from a negative $33.9 \%$ to positive $71.0 \%$, with the average being a positive $12.1 \%$. The negative ROA and negative net profit margin indicate that some firms in our sample were operating at a loss after subtracting all operating expenses. The gross profit margin more tightly captures firm markups and ranges from $4.6 \%$ to a high of $99.8 \%$, with the average of $36.2 \%$. Our sample firms on average spent about $4.6 \%$ of sales on adverting, but one firm spent $50 \%$. Finally, fewer than half of the firms in our sample have no sales outside of North America.

\section{RESULTS}

Before analyzing the results, we tested whether either influential outliers or multicollinearity affected the regression results. DFFITS and DFBETA diagnostic cutoffs as suggested by Kutner et al. (2004) indicated several highly influential outliers that had significant influence over the results. Eliminating these observations from the data set had little effect as the problem cascaded down and other outliers become highly influential. Our solution was to use the logarithm of the independent variables in the regression models to limit the influence of outliers. While using the logarithm reduced the outlier problem, it did not eliminate it. So, the logged variables were winsorized to four standard deviations above and below the mean.
The correlation matrix for the explanatory variables is presented in Table 4. Several of the variables are highly correlated and multicollinearity was a concern. The econometric problem with multicollinearity is that it inflates the variance making it more difficult to achieve significance of the collinear parameters; however, if such collinear estimates are statistically significant, they are as reliable as any other variables in a model. To examine the impact of muliticollinearity on the results, Variance Inflation Factors (VIFs) were calculated for the variables. The VIF scores were all below 10 and multicollinearity was deemed not to be a problem. Thus, while some of the variables are highly correlated with one another, the variables are not correlated with the dependent variable in the same way when included in the multiple regression models.

Table 5 presents the ordinary least squares regression results for the trade promotion models, which all primarily rely upon the strategic profit model. Models 1-3 use strategic profit model broken down into various components to better isolate firm profitability. Model 1 uses ROA as the measure of profitability; Model 2 breaks down ROA into net profit margin and turnover; and Model 3 breaks down the net profit margin into a gross profit margin and an expense ratio. Models 4-6 reexamine Models 1-3, but include some additional interactions that were found by Sudhir and Rao (2006) to be important for explaining trading promotions provided. Two main results can be gleaned from Models 1-3. First, larger firms provide more in trade promotions the coefficient on lnSize is positive and significant in three models. 
Am. J. of Economics and Business Administration 3 (3): 460-472 2011

Table 4: Spearman and pearson correlation matrices of descriptive variables $^{1}$

\begin{tabular}{|c|c|c|c|c|c|c|}
\hline \multirow[b]{2}{*}{ Spearman } & \multicolumn{6}{|c|}{ Pearson correlations $^{1}$} \\
\hline & $\operatorname{lnSize}^{2}$ & $\operatorname{lnROA}$ & InAdvert & lnSaleG & $\operatorname{lnOp} \$$ Flo & lnForeign \\
\hline $\operatorname{lnSize}{ }^{3}$ & & $0.26 * *$ & $0.21^{* *}$ & -0.01 & $0.23 * *$ & $0.58 * *$ \\
\hline InROA & $0.27 * *$ & & 0.01 & -0.02 & $0.43^{* *}$ & $0.24 * *$ \\
\hline InAdvert & $0.29 * *$ & $0.15^{*}$ & & $0.21 * *$ & $0.23 * *$ & $0.39 *$ \\
\hline lnSaleG & -0.97 & 0.06 & $0.16^{* *}$ & & $0.13 *$ & -0.08 \\
\hline $\operatorname{lnOp\$ Flo~}$ & $0.26 * *$ & $0.48^{* *}$ & $0.32 * *$ & $0.12 *$ & & $0.29 * *$ \\
\hline $\operatorname{lnForeign}$ & $0.66 * *$ & $0.30 * *$ & $0.34 * *$ & -0.12 & $0.25^{* *}$ & \\
\hline $\begin{array}{l}{ }^{1} \text { Spearmar } \\
\text { and Pearss } \\
\text { 2} \text { Correlati } \\
\text { identified } \\
\text { (two-taile }\end{array}$ & are ide & es signi & efficient & he .10 & $\begin{array}{l}\text { ted beloy } \\
\text { pove the d } \\
\text { level (tu }\end{array}$ & $\begin{array}{l}\text { e diagona } \\
\text { onal } \\
\text { tailed) are } \\
0.05 \text { leve } \\
\text { definitions }\end{array}$ \\
\hline
\end{tabular}

The lowest level of significance is in Model $3(t=5.05$, $\mathrm{p}<0.01)$. These results support the hypothesis that firms with more potential market power, as measured by total assets, provide more in trade promotions than small firms.

The second main result is that firms that exercise their market power and have higher levels of profitability provide more in trade promotions, as the coefficients for profitability variables are all significant and positive. In Model $1, \ln R O A$ is positive and significant $(\mathrm{t}=2.08, \mathrm{p}<0.05)$, indicating that firms generating higher returns to assets provide higher trade promotions. To isolate whether the results for $\operatorname{lnROA}$ are attributable to manufacturing profitability (profit margin) or operational efficiency (turnover), Model 2 further breaks down lnROA into these components. The results for Model 2 indicate that $\operatorname{lnNetPM}$ is positive and significant $(\mathrm{t}=2.21, \mathrm{p}<0.05)$ but lnTurns is not significant $(t=-0.57, p<0.60)$, which indicates that manufacturers with higher margins and profitability provide significantly more trade promotion fees, but that manufacturers' operational efficiency does not affect trade promotion fees provided. The final breakdown in Model 3 further isolates profitability into pricing power (gross margin) and administrative support (expense ratio). $\ln$ GrM is positive and marginally significant $(t=1.96, p<0.10)$ indicating that firms with higher pricing power provide higher trade promotions. In addition, the expense ratio ( $\ln E x p)$ is negative and significant $(\mathrm{t}=-2.11, \mathrm{p}<0.05)$, which indicates that firms with higher levels of sales, general and administrative expenses provide lower trade promotions. One interpretation of the results on the expense ratio is that manufacturers that have higher expense for other operating expenses provide higher levels of support to retailers and consequently provide less in trade promotions. Overall, these results lend support to the argument that larger more profitable firms provide more in trade promotions to maintain the status quo and to limit competition. None of advertising, sales growth, nor controls for product risk, are significant. Thus, the results do not support the argument that trade promotions are provided to mitigate product failure risk.

Several additional results with regard to Models 13 deserve note. While not reported, the dummy variables for the three-digit SIC industry affiliation code were all significant in all three models, indicating that research into trade promotions should control for industry differences. The control variable for foreign sales (lnForeign) was consistently negative and significant in all the models; the lowest level of significance was in Model $3(\mathrm{t}=-4.68, \mathrm{p}<0.01)$, indicating that firms with larger sales outside of North America provide less trade promotions. One possible explanation for this result is that trade promotions are primarily used as a negotiating tool in North America and less so in other parts of the world. Operating cash flow (lnOp\$Flo) is negative and marginally significant in both Models 2 and 3 $(\mathrm{t}=-1.83, \mathrm{p}<0.10)$ and $(\mathrm{t}=-1.72, \mathrm{p}<0.10)$, respectively. One possible explanation is that higher cash flows are not indicative of providing lower trading promotions, but that firms that do not provide trade promotions in turn have higher cash flow from operations.

Various alternative specifications of the Models 1-3 were examined. One specification substituted market share a firm's lagged sales divided by total industry sales from the United States Census Bureau for a firm's total assets as the size variable. The market share variable, which is highly correlated with size, might be a stronger indicator of market power than total assets since market power is not necessarily derived from assets controlled but from the share of the total sales controlled.

The market share variable was significant in Model $1(\mathrm{t}=2.34, \mathrm{p}<0.05)$, but insignificant in Models 2 and 3 and the other results were econometrically similar. In addition, all model fit statistics declined. Another specification examined whether the percentage of sales to Wal-Mart affected trade promotions provided, since Wal-Mart reportedly does not collect trade promotions (Useem, 2004). The Wal-Mart variable is not significant in Models 1-3 ( $\mathrm{t}=1.14, \mathrm{p}<0.30$, in Model (1) and all other results are econometrically similar. (This variable was included for Wal-Mart's assertion (Walton, 2004-2005) that they do not accept trade promotions).

Two additional dimensions of the trade promotion fee model were examined: Product risk and firm reputation. If trade promotions are compensation for product risk, then trade promotions are expected to be higher when a new untested product is introduced (Desiraju, 2001). 
Am. J. of Economics and Business Administration 3 (3): 460-472 2011

Table 5: Regression results (Dependent variable (TradePro): firms trade promotions as a percentage of sales)

\begin{tabular}{|c|c|c|c|c|c|c|}
\hline $\begin{array}{l}\text { Explanatory } \\
\text { variables }{ }^{1}\end{array}$ & Model 1 & Profit margin & Gross margin & $\begin{array}{l}\text { Model } 4 \\
\text { Size and ROA } \\
\text { Interactions }\end{array}$ & $\begin{array}{l}\text { Model } 5 \\
\text { Size and net } \\
\text { margin interactions }\end{array}$ & $\begin{array}{l}\text { Model } 6 \\
\text { Size and gross } \\
\text { margin interactions }\end{array}$ \\
\hline Intercept & $-0.2380^{* * *}$ & -0.1960 *** & $-0.1920 * * *$ & -0.1260 *** & -0.0340 & 0.1000 \\
\hline $\operatorname{lnSize}$ & $0.0120 * * *$ & $0.0110 * * *$ & $0.0110^{* * *}$ & $0.0060 * *$ & 0.0020 & -0.0050 \\
\hline lnROA & $0.1050^{* *}$ & & & $-1.1100 * * *$ & & \\
\hline $\operatorname{lnNetPM}$ & & $0.1750 * *$ & & & $-1.2730 * * *$ & \\
\hline $\operatorname{lnGrM}$ & & & $0.2010^{*}$ & & & $-1.7480 * * *$ \\
\hline $\operatorname{lnExp}$ & & & $-0.2100 * *$ & & & $1.3290 * *$ \\
\hline $\operatorname{lnTurns}$ & & -0.0090 & -0.0090 & & -0.0940 & -0.1250 \\
\hline lnAdvert & 0.0950 & 0.1060 & 0.1190 & 0.0540 & 0.0760 & 0.0720 \\
\hline lnSaleG & -0.0040 & -0.0140 & -0.0110 & 0.0250 & 0.0030 & 0.0100 \\
\hline lnOp\$Flo & -0.0860 & $-0.1510^{*}$ & $-0.1440^{*}$ & $-0.1520 * *$ & $-0.1640 * *$ & $-0.1550^{*}$ \\
\hline $\operatorname{lnForeign}$ & $-0.1650 * * *$ & $-0.1530 * * *$ & $-0.1480 * * *$ & $-0.1740 * * *$ & $-0.1700 * * *$ & $-0.1730 * * *$ \\
\hline $\operatorname{lnSize} X \ln R O A$ & & & & $0.0680 * * *$ & & \\
\hline $\operatorname{lnSize} X \ln N e t P M$ & & & & & $0.0750 * * *$ & \\
\hline lnSize X $\operatorname{lnTuns}$ & & & & & 0.0050 & 0.0060 \\
\hline $\operatorname{lnSize} X \operatorname{lnGrM}$ & & & & & & $0.1000 * * *$ \\
\hline $\operatorname{lnSize} X \ln \operatorname{Exp}$ & & & & & & $-0.0770 * *$ \\
\hline $\mathrm{N}$ & 193.0000 & 193.0000 & 193.0000 & 193.0000 & 193.0000 & 193.0000 \\
\hline $\mathrm{R}^{2}$ & 0.5550 & 0.5490 & 0.5480 & 0.5800 & 0.5750 & 0.5750 \\
\hline Adj. $R^{2}$ & 0.5100 & 0.5110 & 0.5070 & 0.5450 & 0.5330 & 0.5280 \\
\hline F-statistic & 15.2500 & 14.3500 & 13.3300 & 16.3200 & 13.9100 & 12.3100 \\
\hline Prob > F & 0.0001 & 0.0001 & 0.0001 & 0.0001 & 0.0001 & 0.0001 \\
\hline
\end{tabular}

${ }^{1}$ See Table 1 for variable definitions. * Significant at the .10 level; ** Significant at the .05 level; *** Significant at the .01 level (All two-tailed)

The number of product introductions by sample firms was not readily available, so to proxy for new product introductions, a firm's research and development expense, scaled by lagged sales, was included in the models. If research and development projects are undertaken to develop new products, then it should be a good proxy for product introductions. The research and development variable was not significant in Models 1-3 $(\mathrm{t}=-0.63, \mathrm{p}<0.60$ in Model 1) and all other results were econometrically similar. Finally, Sudhir and Rao (2006) found that firm reputation was negatively correlated with trade promotions, such that firms with higher reputations provide less trade promotions. To proxy for firm reputation, a dummy variable was included for firms included in the Businessweek/Interbrand's ranking of the 100 most valuable brands. Our sample included nine firms (34 observations) that were ranked in the 100 most valuable brands. The rank variable, however, was not significant $(\mathrm{t}=-0.22, \mathrm{p}<0.90$ in Model (1) and all other results were qualitatively similar. To explore higher order effects and examine whether large firms' behavior toward providing trade promotions differs from small firms, Models 1-3 were reexamined by including an interaction term between the size and profitability variables. The interaction terms allow us to more tightly isolate how potential market power (lnSize) and exercised market size (profitability) affect trade promotions provided; these results are reported in Table 5 as Models 4-6. Sudhir and Rao (2006) examined the various interactions between large firms, those with over $\$ 1$ billion in sales and other variables in their model.

The size and profitability interaction terms in Models 4-6 are all positive and highly significant: $\ln$ Size $x \operatorname{lnROA}(\mathrm{t}=3.85, \mathrm{p}<0.01)$, $\ln$ Size $\mathrm{x} \operatorname{lnNetPM}(\mathrm{t}$ $=3.26, \mathrm{p}<0.01)$ and $\operatorname{lnSize} x \operatorname{lnGrM}(\mathrm{t}=3.25, \mathrm{p}<0.01)$. The interpretation of the interaction term is that the rate of trade promotions provided is increasing in a firms' profitability, which is magnified for increasingly larger firms. That is, larger firms with higher profitability provide higher rates of trade promotions than larger firms with lower profitability or smaller firms with higher profitability. These results are consistent with prior findings in Models 1-3, that firms more potential market power (size) and more exercised market power (profitability) provide higher levels of trade promotions. In Model 6, the $\operatorname{lnSize} \times \ln E x p$ interaction also is significant $(\mathrm{t}=-2.54, \mathrm{p}<0.05)$. Post-hoc analysis indicates that larger firms with higher operating expenses provide decreasingly less in trade promotions than smaller firms. This result is consistent with the results in Model 3 and suggests firms provide less trade promotions when operating expenses are higher, but that the decrease is more pronounced for larger firms. Both operating cash flows and foreign sales are negative and significant in Models 4-6, suggesting that firms with higher cash flows and more sales outside of North America provide less in trade promotion fees. Finally, none of the proxies for product risk advertising or sales growth are significant in the model of trade promotions provided. 


\section{DISCUSSION}

The findings of this research support the argument that there is a relationship between the market power of manufacturers and the trade promotions granted. This research finds that both potential market power and exercised market power are positively correlated with trade promotions, which supports the argument that higher power firms, as measured by size and profitability, provide higher trade promotions. This further supports the idea that the practice of providing trade promotions reduces smaller firms' opportunities. Additionally, there is little evidence that the trade promotions provided are functions of risk factors. The implication is that less powerful firms that are unable to provide trade promotions may be excluded from the market. The impact of the high market power firms is that small manufacturers cannot afford to enter the market. Eventually, product variety and product innovation may suffer and the ultimate cost would be borne by the consumers. Further examination of this issue is needed. If it can be shown that the current trade promotion practices restrain trade and inhibit competition, then regulatory intervention and policy changes might be necessary. Public policy reforms could address either the uniformity of trade promotions provided or their elimination altogether. One possible short-term implication for disallowing trade promotions is that consumer prices may increase (FTC, 2001).

An obvious limitation of this research into trade promotion is that no retailer data is examined. Future research should seek to examine this issue from the retailers' perspective. One important example of such research is Sudhir and Rao (2006) who examine trade promotions provided by manufacturers to one retail chain. An additional limitation of this study is the focus on manufacturers in specific industry groups, which limits the generalizability of the results. Future research could seek to expand the sample group into other industry groups that use various distributional channels for delivery of their product. A greater challenge is to separate out various kinds of trade promotions and to not only capture the slotting fee provided to shelve a product, but to refine the amount provided for a particular placement on the shelf.

Early research into an area using previously unused and unavailable data often runs the risk of omitted variables bias and other model misspecification problems. Future research may examine additional and alternative measures of manufacturer market power and product risk. One such extension could be to include actual new product introductions into the model to better examine distributional efficiency issues, since product introductions implicitly have higher risk of failure.

Given the inclusiveness of the new FASB standards for trading promotion, other sources of data must be sought that will allow research to differentiate between the various types. Arguably, coupons are extremely different in their overall marketplace effects from providing a slotting fee for a particular amount or location of shelf space. Further separation of the different components is important for both regulators and marketers to understand negotiated trade promotions. The negotiated aspect of trade promotions needs additional research as well.

\section{CONCLUSION}

To date, the role of trade promotions is still not well understood and clearly more research is needed. Indeed, much of the educational material in textbooks and case studies has little more than a glancing reference to the practice. The value of prime shelf placement is well known, but understanding the dynamics of how much manufacturers are willing to provide for that space is not. Further, anecdotal evidence indicates that high promotional value placed on a blockbuster, "hot" new product mitigates the amount of trade promotions. However, no evidence exists. Finally, the amount of pass-through to consumers of trade promotion money is unknown in this study (Pauwels, 2007). There is obviously more work to be done on this subject.

\section{ACKNOWLEDGEMENT}

This research has been supported through grants from the College of Business and Economics and the Research and Sponsored Programs office at Western Washington University.

\section{REFERENCES}

Ailawadi, K.L. and B.A. Harlam, 2009. Retailer promotion pass-through: A measure, its magnitude and its determinants. Marketing Sci., 28: 782-791. DOI: $10.1287 / \mathrm{mksc} .1080 .0447$

Ailawadi, K.L., B. Norm and P.W. Farris, 1995. Market power and performance: A cross-industry analysis of manufacturers and retailers. J. Retail., 71: 211248. DOI: $10.1016 / 0022-4359(95) 90024-1$

Ailawadi, K.L., P.W. Farris and E. Shames, 1999. Trade promotion: Essential to selling through resellers. Sloan Manage. Rev., 41: 83-92. 
Auh, S. and B. Menguc, 2005. Balancing exploration and exploitation: The moderating role of competitive intensity. J. Bus. Res., 58: 1652-1661. DOI: 10.1016/j.jbusres.2004.11.007

Barnett, W.P., 1997. The dynamics of competitive intensity. Admin. Sci. Q., 42: 128-160. DOI: $10.2307 / 2393811$

Bell, D.R. and X. Dreze, 2002. Changing the channel: A better way to do trade promotions. MIT Sloan Manage. Rev., 43: 42-49.

Bloom, P.N., G.T. Gundlach and J.P. Cannon, 2000. Slotting allowances and fees: Schools of thought and the views of practicing managers. J. Market., 64: 92-108.

Butaney, G. and L.H. Wortzel, 1988. Distributor power versus manufacturer power: The customer role. J. Market., 52: 52-63. DOI: 10.2307/1251685

Buzzell, R.D., J.A. Quelch and W.J. Salmon, 1990. The costly bargain of trade promotion. Harvard Bus. Rev., 68: 141-149.

Cannon, J.P. and P.N. Bloom, 1991. Are slotting allowances legal under the antitrust laws? J. Public Policy Market., 10: 167-186.

Desiraju, R., 2001. New product introductions, slotting allowances and retailer discretion. J. Retail., 77: 335-358. DOI: 10.1016/S0022-4359(01)00050-1

Draganska, M. and D. Klapper. 2007. Retail environment and manufacturer competitive intensity. J. Retail., 83: 183-198. DOI: 10.1016/j.jretai.2007.01.001

Einot, I. and K.R. Gabriel, 1975. A study of the powers of several methods of multiple comparisons. J. Am. Stat. Assoc., 70: 574-583. DOI: $10.2307 / 2285935$

Evans, J.R., 2005. Are the largest public retailers top financial performers? A longitudinal analysis. Int. J. Retail Distrib. Manage., 33: 842-857. DOI: 10.1108/09590550510629428

HANS, 2007. Accounting for Consideration Given by a Vendor to a Customer (Including a Reseller of the Vendor's Products.

FTC, 2001. Report on the Federal Trade Commission Workshop on Slotting Allowances and Other Marketing Practices in the Grocery Industry. 1st Edn., FTC: Washington, DC., pp: 144.

Gomez, M.I., L.M. Maratou and D.R. Just, 2007. Factors affecting the allocation of trade promotions in the U.S. food distribution system. Applied Econ. Perspect. Policy, 29: 119-140. DOI: 10.1111/j.1467-9353.2006.00333.x

Kadiyali, V., P. Chintagunta and N. Vilcassim, 2000. Manufacturer-retailer channel interactions and implications for channel power: An empirical investigation of pricing in a local market. Market. Sci., 19: 127-148. DOI: 10.1287/mksc.19.2.127.11805

Kasulis, J.J., F.W. Morgan, D.E. Griffith and J.M. Kenderline, 1999. Managing Trade Promotions in the context of market power. J. Acad. Market. Sci., 27: 320-332. DOI: 10.1177/0092070399273003

Kelly, K., 1991. The antitrust analysis of grocery slotting allowances: The procompetitive case. J. Public Policy Market., 10: 187-198.

Kelly, T. and M.L. Gosman, 2000. Increased buyer concentration and its effects on profitability in the manufacturing sector. Rev. Indus. Organ., 17: 4159. DOI: 10.1023/A:1007870816171

Murry, J.P. Jr and J.B. Heide, 1998. Managing promotion program participation within manufacturer-retailer relationships. J. Market., 62: 58-68. DOI: 10.2307/1251803

Kutner, M., C. Nachtsheim, J. Neter and W. Li, 2004. Applied Linear Statistical Models. 5th Edn., McGraw-Hill/Irwin, ISBN-10: 007310874X, pp: 1396.

Nijs, V., K. Misra, E.T. Anderson, K. Hansen and L. Krishnamurthi, 2010. Channel pass-through of trade promotions. Market. Sci., 29: 250-267. DOI: 10.1287/mksc.1090.0509

Pauwels, K., 2007. How retailer and competitor decisions drive the long-term effectiveness of manufacturer promotions for fast moving consumer goods. J. Retail., 83: 297-308. DOI: 10.1016/j.jretai.2006.03.001

Rao, A.R. and H. Mahi, 2003. The price of launching a new product: Empirical evidence on factors affecting the relative magnitude of slotting allowances. Market. Sci., 22: 246-268. DOI: 10.1287/mksc.22.2.246.16035

Silva-Risso, J.M., R.E. Bucklin and D. Morrison, 1999. A decision support system for planning manufacturers' sales promotion calendars. Market. Sci., 18: 274-300. DOI: 10.1287/mksc.18.3.274

Sivakumar, K., 2004. Manifestations and measurement of asymmetric brand competition. J. Bus. Res., 57: 813-820. DOI: 10.1016/S0148-2963(02)00463-0

Skibo, J.E., 2007. Corporate Compliance with FASB and EITF: The continuing effects of trade promotion allowance income. SAM Adv. Manage. J., 72: 15-35.

Sudhir, K. and V.R. Rao, 2006. Do Slotting Allowances Enhance Efficiency or Hinder Competition? J. Market. Res., 43: 1-14. DOI: 10.1509/jmkr.43.2.137 
Useem, J., 2004. Should We Admire Wal-Mart? Some say it's evil. Others insist it's a model of all that's right with America. Who are we to believe?

Walton, S.R., 2004-2005. Wal-mart, supplier-partners and the buyer power issue. Antitrust Law J., 72: 509-527.
Wood, L., 1999. Market power and its measurement. Euro. J. Marketing, 33: 612-630. DOI: 10.1108/03090569910262224

Zerrillo, P. and D. Iacobucci, 1995. Trade Promotions: A call for a more rational approach. Bus. Horizons, 38: 69-76. DOI: 10.1016/0007-6813(95)90011-X 